\title{
Biochemical Response of Hybrid Maize (Zea mays L.) to NPK Fertilization Based on Spent Bleaching Earth in Field Scale
}

\author{
Cahya Anugrah ${ }^{1}$, Didik Indradewa ${ }^{1}$, and Eka Tarwaca Susila Putra ${ }^{1, *}$ \\ ${ }^{1)}$ Department of Agronomy, Faculty of Agriculture, Gadjah Mada University, Indonesia
}

\begin{abstract}
Indonesia is one of the largest crude palm oil (CPO) producing countries in the world. To improve oil quality, CPO purification is carried out including bleaching earth. The process produced spent bleaching earth (SBE) and deoiled spent bleaching earth (DSBE) classified as hazardous and toxic materials waste. SBE and DSBE have the potential as an adhesive material in the manufacture of NPK fertilizers. This study aimed to compare the effects of SBE and DSBE on replacing clay minerals in terms of biochemical response. The study was arranged in randomized completly block design with three treatments and blocks. The treatment consisted of NPK fertilizer containing $10 \%$ brown clay (control), NPK fertilizer containing $5 \%$ pure clay minerals $+5 \%$ SBE, and NPK fertilizer containing 5\% pure clay minerals $+5 \%$ DSBE. Data were analyzed using ANOVA and tested using LSD test at a 95\% confidence level. The results showed that NPK containing DSBE was able to increase nitrate reductase activity (NRA) (41.9\%), chlorophyll b content (4.7\%), glycine betaine (GB) (2.5\%), decreasing electrolite leakage (19\%), malondialdehyde (MDA) (23\%) compared NPK containing brown clay. Thus the use of NPK containing DSBE and NPK containing SBE to be able to replace NPK containing brown clay.
\end{abstract}

\section{INTRODUCTION}

Oil palm is a superior plantation commodity in Indonesia with total production reaching 31 million tons and 6.9 million tons of CPO (Crude Palm Oil). CPO is a palm oil containing some pigments, such as carotenoids, xanthofil, and anthocyanin which can reduce oil quality. CPO purification using bleaching earth or adsorbents aims to produce oil consumption. From the CPO refining process, a waste called Spent Bleaching Earth is produced, which is classified as a

*Corresponding author: ekatarwaca79@gmail.com hazardous waste. Heavy metals such as $\mathrm{Ag}, \mathrm{Cr}, \mathrm{Ni}, \mathrm{Pb}$, and $\mathrm{Cd}$ are found in $\mathrm{SBE}$ waste. Heavy metals absorption by roots in high concentrations can interfere with the physiological processes of cultivated plants. The light reaction of photosynthesis, especially in the photosystem II, will decrease in the excitation of electrons to produce energy used in the dark reaction when excess metal accumulation occurs in plant tissue. $\mathrm{CO}_{2}$ diffusion has also been disrupted due to decreased stomatal conductance, which also has an impact on ROS [1]. 
Plants able to tolerate heavy metal stress can increase the enzymatic and nonenzymatic antioxidant activity, thereby reducing cell leakage and regenerating ROS by making osmotic adjustments in cell fluid. Being classified as hazardous and toxic materials. During this time the SBE waste has not been utilized because the management is unknown.

However, spent bleaching earth has the opportunity as an adhesive in the manufacture of NPK compound fertilizer. SBE has physical and chemical characteristics that are relatively the same as adhesives in the manufacture of NPK compound fertilizers which so far has used pure clay mineral material. For this reason, it is necessary to research the effect of biochemical response on maize plants with the application of waste SBE as an adhesive in the manufacture of NPK compound fertilizer. Thus it can reduce the SBE waste produced in the palm oil processing industry.

The estimation that NPK fertilizer with SBE contains heavy metals needs to be proven through this research with indicators of biochemical interference or potential to reduce crop yields and the extent of metal residues left in the soil. The test was carried out on hybrid corn plants due to their responsive characteristics to soil nutrient availability. If there is no residue left due to the SBE application, therefore, it can be suggested that the waste material can be used to replace some of the roles of pure clay minerals.

\section{MATERIALS AND METHOD}

The research was carried out at the Center for Agrotechnoogical Innovation (PIAT), Laboratory of Plant Management and Production, Laboratory of Joint Research Facility, and Laboratory of Analytical Chemistry, Universitas Gadjah Mada University, Indonesia. The research was carried out from November 2018 to March 2019. The material used was a hybrid maize plant cultivar pioneer 36 that has mildew-resistant characteristics and high yield potential. The basic fertilizers used were NPK 15:15:15 compound fertilizer with 5\% SBE and 5\% DSBE with manure.

The research was arranged using a single factor Complete Randomized Block Design (RCBD), consisting of three treatments with four blocks as replications. The treatments tested were NPK fertilizer with $10 \%$ pure clay mineral (control), NPK fertilizer with 5\% pure clay mineral $+5 \% \mathrm{SBE}$, and NPK fertilizer with $5 \%$ pure clay mineral $+5 \%$ DSBE. NPK fertilization was carried out at 14 days after planting at a dose of 300 $\mathrm{kg} / \mathrm{ha}$ and Urea at $36 \mathrm{~kg} / \mathrm{ha}$, and Urea fertilization was performed at 50 days after planting at a dose of $270 \mathrm{~kg} / \mathrm{ha}$. Leaves for observation of biochemical characteristics were taken on the 3rd leaf sequence from the youngest when at the R1 phase.

Biochemical observations are carried out to determine the ROS signal in cells by observing $\mathrm{H}_{2} \mathrm{O}_{2}$ and the impact of ROS activity through MDA and REL observations. Glycine betaine and proline observations were carried out to determine the tolerance mechanism by increasing the osmotic potential and increasing nonenzymatic activity through phenolic observations to minimize cell damage. From the physiological aspects, the activity of nitrate reductase (ANR) and chlorophyll observations were carried out to determine photosynthetic material and nitrogen assimilation enzymes. If biochemical activity is effective it can prevent cells damage and physiological activity is not inhibited.

Biochemical observations made were the activity of nitrate reductase (ANR) based on the method from Hartiko [2], chlorophyll by Arnon method [3], relative electrolyte leakage (REL) measured using method Dionisio-Sese and Tobita [4], $\mathrm{H}_{2} \mathrm{O}_{2}$ by Alexieva method [5], malondialdehyde (MDA) based on the methods of Cakmak and Hernandez $[6,7]$, glycine betaine (GB) measured 
using the method of Grieve and Grattan [8], phenolic compound based on the method of Chum [9], and proline content measured using the method of Bates [10]. The data obtained were analyzed using analysis of variance analysis followed by Duncan Multiple Range Test (DMRT) with a confidence level of $95 \%$. The analysis was performed using SAS software version 9.4.

\section{RESULTS AND DISCUSSION}

The content of heavy metals in the soil at the R1 phase showed that there were differences in the accumulation of heavy metals and micronutrients. Five types of metals and micronutrients tested included $\mathrm{Cr}, \mathrm{Pb}, \mathrm{Cu}, \mathrm{Ag}$, and $\mathrm{Zn}$. The determination was according to the reason that $\mathrm{Cr}, \mathrm{Pb}$, and $\mathrm{Ag}$ can disturb plants at high concentrations by damaging photosynthetic organelles, while $\mathrm{Cu}$ and $\mathrm{Zn}$ can act as micronutrients supporting plant physiology at low concentrations but at high concentrations can poison plants. The heavy metal content of $\mathrm{Cr}, \mathrm{Pb}$, and $\mathrm{Ag}$ accumulated in the soil at the R1 phase was found to be the highest in the $5 \%$ DSBE treatment. Likewise, the micronutrient content of $\mathrm{Zn}$ in the treatment of 5\% DSBE was the highest compared to that in other treatments.

Table 1. Heavy metal content in the soil

\begin{tabular}{lccccc}
\hline Treatment & $\mathrm{Cr}$ & $\mathrm{Pb}$ & $\mathrm{Cu}$ & $\mathrm{Ag}$ & $\mathrm{Zn}$ \\
\hline $\begin{array}{l}\text { NPK fertilizer with 10\% pure clay } \\
\text { mineral (control) }\end{array}$ & $12.09 \mathrm{~b}$ & $35.90 \mathrm{~b}$ & $54.54 \mathrm{a}$ & $3.55 \mathrm{c}$ & $43.57 \mathrm{~b}$ \\
$\begin{array}{l}\text { NPK fertilizer with 5\% pure clay } \\
\text { mineral + 5\% SBE }\end{array}$ & $17.28 \mathrm{ab}$ & $42.65 \mathrm{a}$ & $53.16 \mathrm{a}$ & $7.64 \mathrm{~b}$ & $41.95 \mathrm{~b}$ \\
$\begin{array}{l}\text { NPK fertilizer with 5\% pure clay } \\
\text { mineral + 5\% DSBE }\end{array}$ & $24.42 \mathrm{a}$ & $43.47 \mathrm{a}$ & $55.44 \mathrm{a}$ & $18.28 \mathrm{a}$ & $63.50 \mathrm{a}$ \\
\hline $\begin{array}{l}\text { Coefficient of variation (\%) } \\
\text { Remarks: Means followed by the same letters in the same column are not significantly different } \\
\text { according to Duncan's Multiple Range Test at a confidence level of 95\%. }\end{array}$
\end{tabular}

The high accumulation of heavy metals and micronutrients in the soil unto the R1 phase might indicate that the absorption of the excess heavy metals by plants could be suppressed. The suppression of the absorption of the heavy metals by plants had a better impact because it reduced the level of toxicity, as indicated in the biochemical processes that occur. DSBE is known to contain higher heavy metals as a result of the oil purification process. The oil refining process involves two stages of adsorbent filtering (bleaching earth) so that DSBE has a lower oil and high metals content, however, it has a better impact on plants compared to SBE and pure clay minerals. The impacts were recognized in the biochemical, physiological, and plant growth rates of the maize plants.

NPK fertilizer with $10 \%$ pure clay mineral or substituted with 5\% SBE, and $5 \%$ DSBE had the same characteristics in the accumulation of ROS produced in the form of $\mathrm{H}_{2} \mathrm{O}_{2} . \mathrm{H}_{2} \mathrm{O}_{2}$ is a superoxide regeneration that gets protons so that they become stable and reduce their destructive properties. This showed that when the plants were in the filling phase, the uncharged ROS accumulation in the form of $\mathrm{H}_{2} \mathrm{O}_{2}$ was not significantly different. Although hydrogen peroxide has no charge, it has the character to damage cells or cell membranes.

The formation of $\mathrm{H}_{2} \mathrm{O}_{2}$ begins with the formation of superoxide, which is influenced by the Calvin-Benson cycle activity and the speed of electron flow 
from PSII to PSI. An increase in light absorption from PSII and PSI will increase the transfer of electrons from PSII and PSI to $\mathrm{O}_{2}$ to form superoxide. $\mathrm{H}_{2} \mathrm{O}_{2}$ formation occurs from the results of $\mathrm{O}_{2}$ reduction by two electrons which can be produced in chloroplasts, mitochondria, peroxisomes, and transported across the membrane to the cytosol. Mitochondria can also produce superoxide and $\mathrm{H}_{2} \mathrm{O}_{2}$. Superoxide formation in mitochondria occurs through direct oxygen reduction in the flavoprotein $\mathrm{NADH}$ dehydrogenase enzyme from the transport chain. $\mathrm{H}_{2} \mathrm{O}_{2}$ radicals can diffuse through the cell membrane, having a better level of structural stability, and tend to react with proteins, especially the thiol (-SH) group.
Hydrogen peroxide can be produced in peroxisomes through oxidation reactions such as fatty acid oxidation, the glycosylate cycle (in photorespiration), and purine catabolism. When the oxidative phosphorylation process in the mitochondria occurs, oxygen is reduced by the mitochondrial electron transport system to form ATP and water. During the oxidative phosphorylation process, about $2 \%$ of oxygen molecules can bind to a single electron that leaks from the electron carrier in the respiration chain to form superoxide. Then, superoxide will form hydrogen peroxide by interacting with transition metals such as copper and iron. These free radicals can cause oxidative stress [11].

Table 2. Effects of NPK compound fertilizer on the content of hydrogen peroxide $\left(\mathrm{H}_{2} \mathrm{O}_{2}\right)$, peroxidase (POD), and phenols

\begin{tabular}{lccc}
\hline Treatment & $\mathrm{H}_{2} \mathrm{O}_{2}(\mathrm{ppm})$ & $\begin{array}{c}\text { POD (unit/ml } \\
\text { protein) }\end{array}$ & Phenols (ppm) \\
\hline $\begin{array}{l}\text { NPK fertilizer with 10\% pure } \\
\text { clay mineral (control) }\end{array}$ & $38.18 \mathrm{a}$ & $0.758 \mathrm{a}$ & $400.52 \mathrm{c}$ \\
$\begin{array}{l}\text { NPK fertilizer with 5\% pure } \\
\text { clay mineral + 5\% SBE }\end{array}$ & $39.76 \mathrm{a}$ & $0.687 \mathrm{a}$ & $483.45 \mathrm{a}$ \\
$\begin{array}{l}\text { NPK fertilizer with 5\% pure } \\
\text { clay mineral + 5\% DSBE }\end{array}$ & $38.98 \mathrm{a}$ & $0.553 \mathrm{a}$ & $411.10 \mathrm{~b}$ \\
\hline Coefficient of variation (\%) & 9.85 & 7.3 & 0.45 \\
\hline $\begin{array}{l}\text { Remarks: Means followed by the same letters in the same column are not significantly different } \\
\text { according to Duncan's Multiple Range Test at a confidence level of 95\%. }\end{array}$
\end{tabular}

The hydrogen peroxide accumulated in cells can activate stress signals in tissues. This signal can help plants synthesize organic compounds in the form of enzymatic and non-enzymatic antioxidants. Peroxidase is an enzymatic antioxidant that can be synthesized to convert hydrogen peroxide into oxygen molecules and water molecules. Its accumulation in plants in the form of oxygen and water will not be harmful to plants. In the research, it appears that the availability of substrate and enzymatic activity worked linearly. Thus, peroxidase enzyme activity did not show any significant difference in these observations.
Peroxidase works with the help of energy in the form of NADPH. NADPH can be produced from the photosynthetic light reaction process, which involves the role of chlorophyll a. The peroxidase enzyme catalyzes the reaction of $\mathrm{H}_{2} \mathrm{O}_{2}$ substrate oxireduction. This enzyme has functions related to plant physiological changes such as lignification, suberization, free radical degradation, and auxin metabolism. Peroxidase has a function related to resistance to environmental stress. Peroxidase enzyme activity is due to the binding of - $\mathrm{SH}$ groups and - $\mathrm{COOH}$ groups. An increase in sulfhydryl groups and carboxylates will inhibit the work of the 
enzyme superoxide dismutase and then increase the activity of the peroxidase enzyme [12].

There was a significant effect observed on non enzymatic antioxidant activity in the form of phenolic. NPK fertilizer with 5\% SBE was able to accumulate phenolic compounds in the highest amount compared to NPK fertilizer with 5\% DSBE and 10\% pure clay minerals (14.96\% and $17.15 \%$ respectively). The increase in phenol content in high selenium applications is also due to the increased concentration of phenyl propenyl glycosides (PPGs), which play a role in the phenol pathway. Phenolic is a secondary metabolite that is synthesized based on shikimate pathways. One of the roles of non enzymatic antioxidants is to stabilize ROS in the form of hydroxyl radicals. It was suspected that plants accumulated higher hydroxyl radicals compared to hydrogen peroxide. It was further suspected that plants treated with NPK fertilizer with $10 \%$ pure clay mineral were unable to synthesize excessive amounts of phenolic, affecting the balance of biochemical processes that occur in cells.
Phenolic and polyphenols are natural secondary metabolic products derived from the shikimate or the polyketide pathway. Higher plants synthesize thousands of different types of phenolic compounds, which is influenced by the genetic evolution of the plants and the evolution of the environment. In plants, phenols function as defense compounds under environmental stresses, such as light stress, low temperatures, pathogenic infections, herbivores, and nutritional deficiencies, which will increase the production of free radicals and other oxidative stresses in plant tissue [13]. Antioxidants are compounds that can delay or inhibit the oxidation of lipids or other molecules by inhibiting the initiation or propagation of oxidative chain reactions. Antioxidant activity in fruits and vegetables is related to the total phenol content. Phenols affect redox reactions, which have an important role in absorbing and neutralizing free radicals, counteracting singlets and triplet oxygen, and decomposing peroxide [14]. Phenol is an effective metal chelator removing the catalyst for peroxide decomposition.

Table 3. Effects of NPK compound fertilizer on the glycine-betaine content, relative electrolyte leakage (REL), and proline content

\begin{tabular}{lcccc}
\hline Treatment & $\begin{array}{c}\text { Glycine- } \\
\text { betaine } \\
(\mathrm{ppm})\end{array}$ & $\begin{array}{c}\text { Relative } \\
\text { electrolyte } \\
\text { leakage }(\%)\end{array}$ & $\begin{array}{c}\text { Malondialdehyde } \\
(\mu \mathrm{mol} / \mathrm{fw})\end{array}$ & $\begin{array}{c}\text { Proline } \\
(\mu \mathrm{mol} / \mathrm{g})\end{array}$ \\
\hline $\begin{array}{l}\text { NPK fertilizer with 10\% } \\
\text { pure clay mineral (control) }\end{array}$ & $903.12 \mathrm{c}$ & $18.97 \mathrm{a}$ & $6240 \mathrm{a}$ & $7.88 \mathrm{c}$ \\
$\begin{array}{l}\text { NPK fertilizer with 5\% pure } \\
\text { clay mineral + 5\% SBE }\end{array}$ & $919.25 \mathrm{~b}$ & $16.50 \mathrm{ab}$ & $6282 \mathrm{a}$ & $20.45 \mathrm{a}$ \\
$\begin{array}{l}\text { NPK fertilizer with 5\% pure } \\
\text { clay mineral + 5\% DSBE }\end{array}$ & $926.32 \mathrm{a}$ & $15.34 \mathrm{~b}$ & $4794 \mathrm{~b}$ & $10.80 \mathrm{~b}$ \\
\hline Coefficient of variation $(\%)$ & 0.17 & 6.55 & 3.45 & 5.09 \\
\hline
\end{tabular}

Remarks: Means followed by the same letters in the same column are not significantly different according to Duncan's Multiple Range Test at a confidence level of 95\%.

The balance of biochemical processes and the impact of the unequal phenolics of the three treatments can be observed from the variables of cell membrane leakage and MDA. The plants treated with NPK with $10 \%$ pure clay mineral experienced the highest cell leakage compared with the plants treated with NPK with 5\% SBE and 5\% DSBE. Leaks occur because of the reaction of charged molecules with molecules in the cell membrane. The reacting molecule can 
be in the form of ROS generation. The stability of ROS can be achieved if it gets a charge from lipids or proteins composing the cell membranes. When ROS takes charge from the cell membrane, the cell phospholipid balance becomes disturbed, causing cell leakage. Disorders of phospholipids can be in the form of discharge of materials composing cell membranes. This phenomenon can be observed in the MDA variable. Malondialdehyde is an indicator of lipid peroxidation that occurs in cell membranes due to interactions with unstable charged molecules such as ROS. Lipids which are constituents of cell membranes undergo peroxidation so that many small particles are present in cell fluid, which can interfere with their physiological activity and may affect the cytoplasmic $\mathrm{pH}$.

The lowest malondialdehyde content was observed in the treatment of NPK with 5\% DSBE. The treatment can reduce the accumulation of MDA in the cytoplasm of cells, which can illustrate the low cell leakage. However, the treatment of NPK with $5 \%$ SBE and $10 \%$ pure clay minerals showed the same amount of MDA accumulation. Lipid peroxidation occurs due to changes in the membrane structure, specifically the components and composition of the lipids. Unsaturated fatty acids as the main components of lipid membranes are prone to peroxidation caused by the formation of reactive oxygen. Lipid peroxidation will produce compound products such as aldehydes, alkanes, and hydroxylalkanes. One of the aldehydes is malondialdehyde [15], which is the final product of lipid peroxide. This compound has three carbon chains with the molecular formula of $\mathrm{C}_{3} \mathrm{H}_{4} \mathrm{O}_{2}$. MDA is also a product of decomposition of amino acids, complex carbohydrates, pentose, and hexose.

The process of lipid peroxidase formation starts from hydrogen ions in the side chain (PUFA) composing cell membranes to form carbon radicals. The carbon radical will be oxidized to form a peroxyl radical. Furthermore, the peroxide radical will attract more $\mathrm{H}^{+}$ions in the adjacent PUFA side chains and form lipid peroxidation. This process is a chain reaction because lipid peroxidation will repeatedly attract $\mathrm{H}^{+}$ions in other PUFA side chains until the PUFA chain is finally broken into other compounds such as hydrocarbons, hydroxinonenal, and aldehyde compounds. The result of lipid peroxidation is the formation of MDA [16].

Efforts that can be done by plants in tolerating the reduction of cell leakage and MDA are by osmotic regulation of cells. When exposed to environmental stress, plants need to reduce osmotic potential by accumulating compounds that have small molecular weights and can dissolve without changing the $\mathrm{pH}$ balance in the cytoplasm. These compounds can maintain cell turgidity so that the physiological activity of plants remains stable. Small molecular compounds are produced from an overhaul of large macromolecules stored by plants such as proteins, lipids, or starches. Proline is an amino acid that is produced from a protein overhaul, while glycine is choline produced from an overhaul of phosphatidylcholine composing the cell membrane. Both osmoregulatory can be used as indicators of the plants tolerance.

Based on the observations, the plants treated with NPK with 5\% DSBE could accumulate the highest betaine glycine, and the plants treated with 5\% SBE could accumulate the highest proline. Meanwhile, the plants treated with NPK with $10 \%$ pure clay minerals did not accumulate excess proline and glycine betaine. The presence of an osmoregulator can prove that plants can reduce stress, thereby reducing visible stress indicators. Osmoregulators can help reduce tissue water potential when the water potential in the soil decreases. The decrease in tissue potential occurs by increasing the cytoplasmic solution by producing compounds that can decrease the water potential in the cell so that the water in the 
environment can be absorbed. The production of compounds in the cytoplasm is neutral, not poisonous to the cell, so it does not inhibit the enzymatic activity of the cell at high concentrations. Osmoregulators are also hydrophilic, which can replace water on cell surface proteins, complex proteins, or membranes [17].

The accumulated proline compound can protect the cytosolic enzyme, protect the intercellular structure, and stabilize the membrane by interacting with membrane phospholipids, thus forming membrane integrity. It also functions as a movable and fragmented reserved compound that produces ATP for cell activity and can regulate the $\mathrm{NAD}^{+} / \mathrm{NADH}$ ratio associated with cytosolic acidity. Biosynthesis of betaine glycine is assisted by choline precursors derived from serine, which are converted to aminoethanol becoming choline precursors [18]. Choline is used for the synthesis of lipid components making up the cell membrane, which is the source of the methyl group [19].

A good cell potential regulation will have an impact on the physiological processes such as photosynthetic pigments. The plants treated with NPK with 5\% DSBE had the highest accumulation of chlorophyll a and chlorophyll $b$. The high content of chlorophyll $b$ increased the light captured by the pigment, which contributed to the formation of energy carried out by chlorophyll a. The energy produced, ATP and NADPH, were used as the main ingredient in simple sugars production in the photosynthesis dark reaction. Besides, the improvement of nitrate reductase activity in the plants treated with NPK with $5 \%$ DSBE affected the changes in nitrogen assimilation in cells. Nitrate reductase activity plays a role in changing the nitrogen (nitrate or ammonium) absorbed by plants. Large amounts of nitrate reductase activity can produce amino acids, hormones, pigments, and other molecules that can support the metabolism of plants.

Table 4. Effects of NPK compound fertilizer on the nitrate reductase activity (NRA), chlorophyll a and chlorophyll b

\begin{tabular}{|c|c|c|c|}
\hline Treatment & $\begin{array}{l}\text { Nitrate reductase } \\
\text { activity } \\
\left(\mu \mathrm{mol} \mathrm{NO}_{2}^{-} / \mathrm{g}^{-} \mathrm{h}\right)\end{array}$ & $\begin{array}{l}\text { Chlorophyll a } \\
(\mathrm{mg} / \mathrm{g})\end{array}$ & $\begin{array}{c}\text { Chlorophyll b } \\
(\mathrm{mg} / \mathrm{g})\end{array}$ \\
\hline $\begin{array}{l}\text { NPK fertilizer with } 10 \% \text { pure } \\
\text { clay mineral (control) }\end{array}$ & $127.03 \mathrm{c}$ & $31.02 \mathrm{a}$ & $45.62 \mathrm{~b}$ \\
\hline $\begin{array}{l}\text { NPK fertilizer with } 5 \% \text { pure clay } \\
\text { mineral }+5 \% \text { SBE }\end{array}$ & $218.73 \mathrm{~b}$ & $30.24 \mathrm{~b}$ & $47.88 \mathrm{a}$ \\
\hline $\begin{array}{l}\text { NPK fertilizer with } 5 \% \text { pure clay } \\
\text { mineral }+5 \% \text { DSBE }\end{array}$ & $361.65 \mathrm{a}$ & $30.72 \mathrm{a}$ & $47.91 \mathrm{a}$ \\
\hline Coefficient of variation $(\%)$ & 3.11 & 0.52 & 1.66 \\
\hline
\end{tabular}

Nitrate reductase is found in almost all organs of plants, especially when nitrate is the nitrogen source of the plant. Nitrate reductase activity is in the leaves or the roots of plants. This enzyme is found in certain locations in plant cells. In nitrate reductase maize, the enzyme is found in the root epidermis and symplastic pathways for ion transport (to keep nutrients separate from the cytoplasm) to streamline the translocation of nutrients from root to leaf [20]. Chlorophyll a gives blue-green color, and chlorophyll $b$ gives a yellow-green color. The content of chlorophyll a is higher than that of chlorophyll $b$ in leaf tissue [15]. The molecular formula of chlorophyll a and chlorophyll $b$ is $\mathrm{C}_{55} \mathrm{H}_{72} \mathrm{~N}_{4} \mathrm{O}_{5} \mathrm{Mg}$ and $\mathrm{C}_{55} \mathrm{H}_{70} \mathrm{~N}_{4} \mathrm{O}_{6} \mathrm{Mg}$, respectively. Chlorophyll 
directly plays a role in the conversion of radiation energy into chemical energy and absorbs as well as transports energy to the molecular reaction center. Meanwhile, chlorophyll $\mathrm{b}$ serves to absorb radiation energy, which is then forwarded to chlorophyll a.

Table 5. Effects of NPK compound fertilizers on the photosynthesis rate and crop growth rate

\begin{tabular}{lcc}
\hline Treatment & $\begin{array}{c}\text { Photosynthesis rate } \\
\left(\mu \mathrm{mol} / \mathrm{CO}_{2} / \mathrm{m}^{2} / \mathrm{s}\right)\end{array}$ & $\begin{array}{c}\text { Crop growth rate } \\
\left(\mathrm{g} / \mathrm{cm}^{2} / \text { day }\right)\end{array}$ \\
\hline $\begin{array}{l}\text { NPK fertilizer with 10\% pure clay } \\
\text { mineral (control) }\end{array}$ & $127.58 \mathrm{~b}$ & $4.164 \mathrm{c}$ \\
$\begin{array}{l}\text { NPK fertilizer with 5\% pure clay } \\
\text { mineral + 5\% SBE }\end{array}$ & $129.17 \mathrm{~b}$ & $8.454 \mathrm{a}$ \\
$\begin{array}{l}\text { NPK fertilizer with 5\% pure clay } \\
\text { mineral + 5\% DSBE }\end{array}$ & $162.67 \mathrm{a}$ & $6.334 \mathrm{~b}$ \\
\hline
\end{tabular}

Coefficient of variation (\%) $10.24 \quad 10.02$

Remarks: Means followed by the same letters in the same column are not significantly different according to Duncan's Multiple Range Test at a confidence level of 95\%.

The increased availability of energy as a result of the light reaction of photosynthesis causes an increase in the photosynthesis rate. The increase in the photosynthesis rate of the plants treated with NPK with 5\% DSBE was higher compared to that of the plants treated with NPK with $5 \%$ SBE and $10 \%$ pure clay minerals. The increasing photosynthesis rate can contribute to the assimilation distributed to the organs of the plants. The plants treated with NPK with 5\% DBSE showed a higher crop growth rate compared to the plants treated with NPK with $10 \%$ pure clay. The daily increase in dry weight of plants, observed from the variable of maximum crop growth rate, can increase crop economic yields. If the economic yield of plants is high, the plants are able to tolerate the use of NPK fertilizer with $5 \%$ pure clay mineral added with $5 \%$ DSBE.

\section{CONCLUSION}

The provision of NPK compound fertilizer with 5\% SBE and 5\% DSBE did not cause a biochemical disturbance that is harmful to plants. Therefore, it does not potentially reduce the yield of corn. DSBE waste can be used as supplementary material in the manufacture of NPK compound fertilizer.

\section{Acknowledgement}

Authors would like to thank to the Wilmar International Ltd for funding of this research.

\section{References}

1. A.L. Singh, R.S. Jat, V. Chaudhari, H. Bariya, S.J. Sharma, J. Plant. Stress. Physiol 4, (2010)

2. H. Hartiko, E.J. del-Rosario, Bull. Phil. Biochem. Soc 3, (1980)

3. D.I. Arnon, Plant. Physiol 24, (1949)

4. M.L. Dionisio-sese, S. Tobita, Plant. Sci 135, (1998)

5. V. Alexieva, I. Sergiev, S. Mapelli, E. Karanov, Plant. Cell. Environ 24, (2001)

6. Cakmak, W.J. Horst, Plant. Physiol 83, (1991)

7. J.A. Hernandez, M.S. Almansa, Plant. Physiol 115, (2002)

8. C.M Grieve, S.R. Grattan, Plant. Soil 70, (1983)

9. O.K. Chun, D. Kim, C.Y. Lee, J. Agric. Food. Chem 51, (2003)

10. L.S. Bates, R.P. Waldren, I.D. Teare, Plant. Soil 39, (1973) 
11. E.K. Untari, S. Wahdaningsih, A. 16. T. Nagao, Y. Komine, S. Soga, S. Damayanti, Pharm. Sci. Res 1, (2014)

12. A.A. Ferdhiani, S. Lestari, E. Proklamasiningsih, Biosfera

32, (2015)

13. V. Lattanzio, Natural products (Springer, 2013)

14. Daniel, N.G. Subramaniyan, K. Chinnannan, I.A. Padikasan, Int. Res. J. Basic. Appl. Sci 6, (2015)

15. L.N. Kurganova, A.P. Veselov, Y.V. Sinistina, E.A. Elikova, Plant. Physiol 46, (1999)

21. 88$)$ Meguro, T. Hse, Y. Tanaka, I. Tokimitsu, Am. J. Clin. Nutr 81, (2005)

17. N. Mohammadkhani, R. Heidari, World. Appl. Sci. J 3, (2008)

18. J. Bremer, P.H. Figard, D.M. Greenberg, Biochim. Biophys. Acta 43, (1960)

19. V. Michel, Z. Yuan, S. Ramsubir, M. Bakovic, Exp. Bio. Med 231, (2013)

20. W.H. Campbell, Physiol. Plant 74, (19 